\title{
On the Improvement in the Quality of Teaching Affair Administration in Colleges and Universities
}

\author{
Ying Zhou \\ Teaching Affairs Department of Bohai University, Jinzhou Liaoning, 121000
}

Keywords: teaching affair administration in colleges and universities; work quality; improvement

\begin{abstract}
In the development of higher education, the system of teaching affair administration is one of basic guarantee factors, and the planning, objective and scientificity of teaching affair management shall be emphasized. This paper conducts detailed research on characteristics of teaching affair administration in colleges and universities, puts forward problems in teaching affair administration, and explores strategies of improving the quality of teaching affair administration so as to provide theoretical reference for the staff on the front line.
\end{abstract}

In the management of colleges and universities, teaching affair administration is the core content. At present, higher education is now developing rapidly, reform in educational system is continuously deepening, therefore, there are more social and educational responsibility for colleges and universities to shoulder. So how to improve the quality of teaching affair administration in colleges and universities is the important task for each and every college and university to study.

\section{Characteristics of teaching affair administration in colleges and universities}

With the continuous deepening of educational reform, colleges and universities embrace new challenges in the development. The teaching activities, the teaching order, and the improvement of teaching quality all require scientific and effective teaching affair administration as an important guarantee, which is special, specifically, the daily management activities such as the construction system, implementation supervision, team cooperation and management must be optimized and improved in accordance with the changes in the form, so as to promote the continuous improvement of the quality of teaching affair administration in colleges and universities.

\section{Problems exist in teaching affair administration in colleges and universities.}

\subsection{Ambiguous rights and liabilities planning}

Most colleges and universities use secondary management methods. The leader of teaching affair administration is still the teaching affairs department, which is because the staff is not sufficient, and the workload is increasing at the same time, at the same time, the responsibilities, and the pressure on the management staff, but in this case, the relevant welfare policies and salary of management personnel has not been correspondingly improved, resulting in problems in the work style and attitude of staff in teaching affair administration. Leaders in teaching affair administration have insufficient rights. The university has set up corresponding work in each department. Since there is not explicit regulation in many management systems, the university do not have enough rights to interfere, so many decisions need review and opinions of other relevant departments, which undoubtedly causes the complicated work.

\subsection{The enthusiasm of learning of teachers and students ignored.}

At present, teachers and students are the subject in the teaching affair administration in colleges and universities, however, there are some problems in the process. Teachers are the integral part of teaching activities and the administration system of teachers shall ensure that the enthusiasm of teachers can be stimulated to effective improve teaching level and efficiency of teachers. Whereas, 
the current teaching affair administration cannot sufficiently and effectively mobilize the initiative of teachers. It is important for teachers to accomplish teaching objectives, not just transmit knowledge, which hinders the improvement in teaching level of teachers. The current teaching affair administration implements teaching system and student status management system, which is not helpful for the development of students and their initiative for independent learning.

\subsection{Lack of constraints and external incentives.}

In recent years, the composition of expenditure for higher education institutions in our country has become increasingly diversified, mainly including government grant and college self-pay. At present, many colleges and universities are independent and all expenditure are paid by themselves. Therefore, in this way, it is impossible to satisfy the improvement in the quality of higher education and strengthen the healthy development of the college itself. The economic investment has laid the foundation for the development of the college, which can not only affect the operation of the college, but also can be linked to all aspects of the college. Most colleges do not pay much attention to the teaching affair administration system, instead of investing the limited funds mainly in teaching equipment and supporting facilities, which undoubtedly hinders the improvement in the quality of teaching affair administration in colleges and universities. Most colleges have a relatively small number of people. Therefore, there is unclear division of work in the allocation of human resources. As a result, a person needs to assume a variety of duties, causing great pressure on the staff and impeding the improvement in the quality of teaching affair administration. Insufficient investment in the allocation of information resources leads to aging problems in the teaching affair administration system, and advanced equipment and software cannot be innovated and adopted, which is ultimately disadvantageous to teaching affair administration. In this way, chaos in information, such as students, courses, and achievements, etc. will occur, and activities will not be able to be carried out smoothly. Therefore, the fund is one of the important factors to ensure the improvement in the quality of teaching affair administration. In conclusion, the investment in this area is very important, which is the fundamental driving force for improving the quality of teaching affair administration. However, in such an incentive and assessment system, it is very likely that a rush for quick results and corruption problems will appear. Some colleges and universities may also unilaterally pursue the government's assessment and thus do not attach importance to the substantive development of the teaching. The supervision methods of teaching affair administration in colleges and universities are very simple, lacking a diversified supervision system. With the continuous development of information society, social supervision has gradually appeared in front of everyone, many colleges and universities apply follow-up evaluation of graduates for the ranking and appraisement in teaching affair administration, however, this evaluation method has not been highly valued highly. In society, there has been no strong reaction to such evaluation method, which has not an important impact on school selection of students. Therefore, the external incentives for the teaching affair administration in colleges and universities are very important.

\section{Strategies for the improvement in the quality of teaching affair administration in colleges and universities.}

\subsection{To improve teaching affair administration system.}

First of all, the gradual improvement of the teaching affair administration system in colleges and universities shall be taken as the primary goal of the teaching affair administration work, so as to promote the gradual development of the teaching affair administration management system that can be scientific, standardized, and innovated with the times, and establish a set of teaching affair administration system including examination, student status, management, and daily resources, and can ultimately ensure that the teaching affair administration work can be conducted in a structured and valid manner. Secondly, it is necessary to establish a sound supervision and execution system and strengthen the implementation of the supervision in order to ensure the high quality of teaching affair administration. The teaching affair administration system shall be constantly improved, the 
implementation of administration strengthened, and the management of teaching quality reported timely, and the teaching mode can fully and effectively run, and ultimately the quality of teaching affair administration can be improved.

\subsection{To improve competition incentive mechanism.}

Firstly, the incentive mechanism built shall be reasonable and scientific, and the administration mode shall be modern, which can encourage the staff to learn modern management software, improve their professional proficiency and ensure the smooth implementation of administration. Secondly, in effective teaching affair administration, colleges and universities should promote the competition mechanism so as to mobilize the emphasis on system of rewards and penalties from the staff in teaching affair administration and their enthusiasm for the work to obtain sense of honor from the work. Besides, colleges and universities should strengthen the formulation of professional title appraisal and promotion in order to provide a vast career development platform for the staff and obtain sense of honor from the work. Meanwhile, employees who are slack in their teaching affair administration work shall be criticized and punished, and those who have serious problems should be transferred away from the work. Finally, in the teaching affair administration in higher education institutions, it is necessary to establish the management concept of talent cultivation, correctly and positively guide the personnel of teaching affair administration, strengthen the subjective awareness of the personnel, and combine with the teaching resources to rationally carry out teaching and research.

\subsection{To develop harmonious interpersonal relationship and cooperation team.}

In colleges and universities, in order to improve the quality of teaching affair administration, the personnel should have the spirit of cooperation and team-work, which will be indicated in both the efficiency and improvement in the quality of teaching affair administration. Whether the entire team of personnel has the spirit of selfless dedication and teamwork can show the basic proficiency level of the team, including its own value reflected and other teaching affair administration task accomplished. In effective teaching affair administration, good interpersonal relationship is an important prerequisite for its effectiveness and quality. In the process of forming benign interpersonal relationship, it is necessary to pay attention to the effective development of communication and cooperation, and thus play a role in transition from complex process into simple one. Material, financial, and human resources in the teaching process should be reasonably and scientifically arranged, and teaching resources are rationally optimized so as to promote teaching work to achieve the best results. At present, in some colleges and universities, the teaching affair administration is very loose, which is a task that needs the communication with many departments. Among them, students and teachers are main helpers. The personnel in teaching affair administration need communication skills to be good at communicating with people. The personnel of the administration communicate well with the relevant personnel of the department, so as to understand the problems arising from teachers and students in the teaching process and coordinate and deal with these issues so as to promote the steady development of the teaching and comprehensively serve teachers and students.

\subsection{To enhance the application of science and information technology.}

With the incessant development of modern information and the deepening of the application of information technology in education, due to the work content, the personnel in teaching affair administration need to receive and deal with a large quantity of information, which requires the personnel to keep pace with the times, rapidly and effectively accomplish administration work and improve the construction of information on campus with modern information technology. The teaching affair administration in the college mainly includes the teaching, grades and other aspects of students and implements modern educational management, in fact, real information organized and shared in the platform by relevant personnel, and science technology can help the personnel in the traditional and complicated work, which can save the cost and labor force and promote the continuous improvement in the quality of teaching affair administration. 


\section{Conclusion}

The teaching affair administration is the integral part in colleges and universities and the important guarantee for the cultivation of highly-competent talents. The fully understanding of teaching affair administration and the implementation of effective teaching affair administration system well accepted by students can promote the improvement in the quality of teaching affair administration and lay the foundation for the smooth implementation of other works in colleges and universities. Colleges and universities should break away from the constraints of traditional concepts, deepen the reform in teaching affair administration modes, incessantly improve the quality of effective teaching affair administration and promote the continuous development of teachers and students.

\section{References}

[1] Luo Xiaozhen. On the Concept of Digitalization in Teaching Affair Administration in Colleges and Universities [J]. Journal of Chifeng University (Natural Science Edition), 2016, 32(06): 207-208.

[2] Wu Wei. Discussion on Diversified Teaching Affair Administration in Colleges and Universities [J]. Contemporary Vocational Education, 2016, (10): 39-42.

[3] Wu Xiaoling, Deng Xiaoqun. Requirements of Competence and Measures of Improvement for the Personnel in Teaching Affair Administration in Colleges and Universities [J]. Brand, 2015, (06): 242-243.

[4] Xu Ting. Strategies to Promote Teaching Management [J]. Journal of Zhejiang Business Technology Institute, 2014 (01): 65-67.

[5] Zhang Qingfang. On the Improvement in the Efficiency of Teaching Affair Administration in Colleges and Universities [J]. Journal of Shangqiu Normal University, 2013 (10): 121-123.

[6] Xie Xuexiang. Research on the Efficiency and Improvement in Quality of Teaching Affair Administration in Colleges and Universities [J]. Journal of Lanzhou Institute of Education, 2016 (01): 78-79. 